\title{
4: 74971310-74974468
}

National Cancer Institute

\section{Source}

National Cancer Institute. 4: 74971310-74974468. NCI Thesaurus. Code C45111.

Physical location of IL8_Gene 